\title{
OCCURRENCE AND MINERALOGY OF THE MARGARITE- AND MUSCOVITE-BEARING PSEUDOMORPHS AFTER TOPAZ IN THE JUURAKKO PEGMATITE, ORIVESI, SOUTHERN FINLAND
}

\author{
SEPPO I. LAHTI
}

\begin{abstract}
LAHTI, SEPPO I., 1988: Occurrence and mineralogy of the margarite- and muscovite-bearing pseudomorphs after topaz in the Juurakko pegmatite, Orivesi, southern Finland. Bull. Geol. Soc. Finland 60, Part 1, 27-43.

Margarite- and muscovite-bearing pseudomorphs after topaz are described from the Juurakko pegmatite dyke, Orivesi, southern Finland. A supercritical vapour phase rich in calcium and alkalies caused alteration of topaz and some other silicates during final phase of crystallization of the dyke.

The original columnar form of topaz crystals is characteristic in the pseudomorphs, although roundish or irregular mica aggregates are also common. The pseudomorphs are composed of fine-scaled, light-brown muscovite, but they may have a topaz-margarite or margarite core. Coarse-scaled pink, lilac or yellow muscovite forms a rim around the pseudomorphs.

The muscovites are nearly ideal dioctahedral. The amount of paragonite and phengite substitution is minute. The pink muscovite is slightly enriched in Mn, but the mica is poor in Fe. Margarite is fibrous or massive, fine-scaled and white in colour. The fibre axis is either a crystallographic $\mathrm{a}$ or $\mathrm{b}$ axis. Microprobe analyses show that the composition of margarite varies largely from one crystal to the other. The mineral has appreciable paragonite and ephesite as solid solution.

Fine-scaled muscovite is also a main mineral in the pseudomorphs after schorl and garnet. The pseudomorphs after topaz and tourmaline may be similar. The prismatic form and the hexagonal cross-section is, however, often well-preserved in the pseudomorphs after tourmaline and the muscovite is richer in $\mathrm{Fe}, \mathrm{Mg}, \mathrm{Mn}$, and Ti. The muscovite in the pseudomorphs after garnet has also appreciable phengite component. Being composed of bertrandite or fine-grained bertrandite, chlorite and muscovite mass, the pseudomorphs after beryl differ from the pseudomorphs after topaz and tourmaline in mineralogy.
\end{abstract}

Key words: margarite, muscovite, topaz, pseudomorphism, chemical composition, pegmatite, Juurakko, Eräjärvi, Orivesi, Finland.

Seppo I. Lahti: Geological Survey of Finland, SF-02150 Espoo, Finland.

\section{Introduction}

Pegmatite studies carried out by the author within the Eräjärvi pegmatite area in Orivesi, southern Finland, revealed that pseudomorphs after various Al-bearing silicates, and $\mathrm{Li}$ and $\mathrm{Fe}$ Mn phosphates are common in larger lithium and beryl-columbite pegmatites. Several examples have been reported by Lahti (1981), and by Lahti and Saikkonen (1985). The present study describes the mica pseudomorphs of the Juurakko pegmatite dyke, which is one of the largest complex pegmatite bodies of the area. A supercritical vapour phase rich in potassium, calcium, 
sodium and lithium was relased from the pegmatite magma and caused alteration of topaz, tourmaline, beryl and garnet during the final phase of crystallization of the dyke.

The columnar form with some typical crystal faces is well preserved in the pseudomorphs after topaz, although irregular or roundish aggregates are also common. The pseudomorphs are composed of fine-scaled muscovite and they may have a topaz-margarite or margarite-muscovite core. In some specimens margarite is exceptionally fibrous in appearance.

Margarite, which usually occurs in the low to medium-grade metamorphic $\mathrm{Ca}$ - and Al-rich schists and replaces sillimanite, andalusite, kyanite or corundum (Guidotti and Cheney 1976; Baltatzis and Katagas 1981; Frey et al. 1982; Guidotti 1984), is here an alteration product of topaz. To the knowledge of the author, no similar occurrence of margarite has ever been described from granitic pegmatites (Hawthorne and Č̉erný 1982, Č erný and Burt 1984); only intermediate forms between bityite, $\mathrm{Ca}_{2} \mathrm{Li}_{2} \mathrm{Al}_{4}$ $\left(\mathrm{Si}_{4} \mathrm{Al}_{2} \mathrm{Be}_{2}\right) \mathrm{O}_{2 \mathrm{O}}(\mathrm{OH})_{4}$, and margarite, $\mathrm{Ca}_{2} \mathrm{Al}_{4}$ $\left(\mathrm{Si}_{4} \mathrm{Al}_{4}\right) \mathrm{O}_{2 \mathrm{O}}(\mathrm{OH})_{4}$, have been found in pegmatites. These micas, however, usually occur as an alteration product in pseudomorphs after beryl (Černý 1968; Arnaudov et al. 1982; Kutukova 1959). Fine-scaled bityite has also been described in pseudomorphs after beryl in some lithium pegmatite dykes of the Eräjärvi area (Lahti and Saikkonen 1985). No bityite or related Be-bearing brittle micas have been encountered in the Juurakko pegmatite, and the mineralogy of the pseudomorphs after beryl is quite different from that of the pseudomorphs after topaz.

The pseudomorphs after tourmaline (schorl) contain only muscovite as an alteration product and resemble the pseudomorphs after topaz. However, the original hexagonal cross-section of the tourmaline crystals may be well preserved in the pseudomorphs, and muscovite is richer in $\mathrm{Fe}$, $\mathrm{Mn}, \mathrm{Mg}$ and $\mathrm{Ti}$ than in the pseudomorphs after topaz.

For this study numerous columnar mica pseu- domorphs (usually $0.5-5.0 \mathrm{~cm}$ in diameter) or larger pieces of mica-topaz aggregates were collected from the locality. The aim of this article is to characterize the occurrence and mineralogy of these pseudomorphs. Special attention is paid to the chemistry of margarite and other micas in the pseudomorphs after topaz, because the author has not found any descriptions of similar margarite-muscovite pseudomorphs in the literature.

\section{General geology of the pegmatite dyke and the occurrence of mica pseudomorphs}

The mineralogy and geology of the Juurakko dyke (map sheet 214109 , grid coordinates $\mathrm{x}=$ $6829800, y=2528160$ ) have previously been briefly described by Lahti (1981 and 1986). The general geological features of the surrounding Proterozoic schists, gneisses and plutonic rocks are shown on sheets 2141 Kangasala (Matisto 1964, see also the explanation to the map, Matisto 1976) and 2142 Orivesi (Laitakari 1986) of the geological map of Finland.

The Juurakko pegmatite is a large subhorizontal dyke more than $12 \mathrm{~m}$ thick, 50-100 m wide and several hundred metres long. Horizontally it is forked and poorly defined. It is surrounded by a small quartz diorite stock and mica schists. The pegmatite was quarried mainly for feldspar and quartz from the beginning of this century until about twenty years ago, when operations ceased. The main quarry is about $60 \mathrm{~m}$ in diameter and at least $10 \mathrm{~m}$ deep. There are another three smaller quarries in the immediate vicinity, but all four are now filled with water.

The Juurakko pegmatite has three clearly defined zones. Outermost, towards the wall rock, is the border zone. It is about $50 \mathrm{~cm}$ thick and consists mainly of albitic plagioclase and quartz with minor microcline, muscovite and schorl. The border zone is followed inwards by the wall zone and the intermediate zone. Several quartz cores, the biggest of them some metres in diameter, 
characterize the central parts of the dyke. The abundance of microcline and muscovite and the grain size of the minerals increase progressively from the border zone to the wall and intermediate zones. The K-feldspar crystals are usually less than $10 \mathrm{~cm}$ long in the border zone and 10-50 $\mathrm{cm}$ long in the wall zone; in the intermediate zone, however, they may be gigantic and several metres long. Graphic granite is typical of the wall zone of the dyke.

Black tourmaline is a characteristic accessory mineral throughout the dyke, and the crystals may be up to $10 \mathrm{~cm}$ in diameter. The tourmaline crystals of the albite-quartz-muscovite rock between the huge microcline crystals in the intermediate zone may be surrounded by a rim of massive muscovite. Muscovite replaces tourmaline, and sometimes the original crystals are totally altered.

Sugary albite or cleavelandite-rich replacement bodies and fracture fillings characterize the central parts of the dyke. The last to crystallize, these are the parts favoured by the rare pegmatite minerals. Pale yellow or pink beryl, cassiterite, $\mathrm{Mn}$ and Fe columbite, zircon, almandine-spessartine and fluorapatite are abundant in the pegmatite. Green tourmaline is very rare and lepidolite has not been identified for sure.

Mica aggregates with a topaz core have been encountered in only one of the quarries, but totally altered muscovite and muscovite-margarite pseudomorphs after topaz and other silicates occur throughout the pegmatite. Fine-scaled mica pseudomorphs are typical of the fracture fillings with sugary or platy albite, quartz and muscovite as major minerals. Fine-grained massive chlorite-bertrandite-muscovite pseudomorphs after beryl occur in much the same way. Two specimens were encountered in which a columnar mica pseudomorph after topaz is inside a big, hexagonal bertrandite-chlorite pseudomorph after beryl, indicating that topaz crystallized before beryl and was altered later or at the same time as beryl.

Thin quartz veins, quartz-schorl and löllingite- sphalerite-pyrite veins, which sharply cut all parts of the pegmatite crystallized in the final stages. Microcline, albite, quartz and bertrandite occur as euhedral crystals in cavities and represent the final crystallization phases of the hydrothermal solutions.

\section{Study methods}

The mica pseudomorphs were first cut into two equal pieces: one for polished thin sections, the other for mineral identification and chemical analyses. The micas were identified from the $\mathrm{X}$ ray powder diffraction patterns recorded with a Philips diffractometer or a Debye-Scherrer camera (diam. $57.3 \mathrm{~mm}$ ). The fibrous margarite was studied in detail with the X-ray single crystal and diffractometer methods. A Buerger precession camera was used to determine the relations of the fibre axis and the crystallographic axes of the mineral. The unit cell dimensions of the margarite were computed from the X-ray powder diffractogram recorded using $\mathrm{Ni}$-filtered $\mathrm{Cu}$ radiation $(\lambda \mathrm{CuK} \alpha=1.5418 \AA)$, a scanning speed of $1 / 42$ theta $\%$ min., and $\mathrm{NaCl}$ as an internal standard.

Several polished thin sections of the pseudomorphs were studied under the microscope and subsequently with microprobe methods. The microprobe analyses were done at the University of Oulu and at the Geological Survey of Finland with a JEOL electron microprobe. The analysing conditions for the quantitative analyses were $15 \mathrm{kV}$ accelerating voltage, approximately $30 \mathrm{nA}$ probe current and a beam diameter of about 1 $\mu \mathrm{m}$. An energy-dispersive spectrometer system (EDS) was used to locate the different micas of the pseudomorphs. Usually some mica crystals from three different part between the core and rim of the pseudomorph or from different zones were analysed. Natural minerals were used as standards.

A powdered sample of the margarite specimen studied in detail was analysed separately with an 
inductively coupled plasma-atomic emission spectrometer (ICP-AES). The trace elements of the micas were determined with ICP-AES, but some elements were assayed with optical emission spectrography (OES), atomic absorption spectrophotometry (AAS), or X-ray fluorescence (XRF). Some specimens were analysed for water on a LECO RMC moisture determinator, and for fluorine using a fluoride ion-selective electrode. The OES, AAS, XRF, and ICP-AES, and fluorine and water determinations were all done at the Geological Survey of Finland.

\section{Mica aggregates after topaz}

The irregular, roundish or oval mica aggregates are considered pseudomorphs after topaz crystal aggregates or anhedral topaz crystals. The pseudomorphs are composed of very fine-scaled, light-brown muscovite, but they may have a topaz-margarite or margarite-muscovite core. The aggregates are rimmed by coarse-scaled, yellow, pink or lilac lepidolite-like muscovite. Graphite commonly occurs as disseminated grains or stripes in the fine-scaled muscovite or as accumulations around the pseudomorphs.

\section{Mineralogy of a homogeneous mica aggregate}

The homogeneous mica aggregate studied in detail is $20 \times 20 \times 10 \mathrm{~cm}$ in size and is composed of very fine-scaled, light-brown, massive muscovite (scales $0.01-0.20 \mathrm{~mm}$ in diameter). The aggregate is rimmed by coarse-scaled, pink or lilac muscovite (scales $0.5-3.0 \mathrm{~cm}$ in diameter).

The microprobe studies show that the composition of the mica differs little within the pseudomorph. In Table 1, analyses 1 and 2 refers to the fine-scaled muscovite, and analyses 3 and 4 to the pink muscovite. Both micas are nearly ideal dioctahedral muscovite in formula. The contents of the minor elements ( $\mathrm{Fe}, \mathrm{Mn}$ and $\mathrm{Na}$ ) are low. Pink muscovite has more Mn (up to $0.9 \mathrm{wt} \%$ $\mathrm{MnO}$ ) than the fine-scaled muscovite and is poorer in $\mathrm{Fe}(\mathrm{Mn} / \mathrm{Fe}=10-16)$. The $\mathrm{Na} /(\mathrm{Na}+\mathrm{K}) \mathrm{ra}-$ tio is $0.07-0.08$, being somewhat lower in the fine-scaled muscovite. The trace elements of the micas are shown in Table 4 (no. 4: fine-scaled muscovite, no. 6: pink muscovite).

\section{Mineralogy of a zoned mica-topaz aggregate}

The minerals of the large zoned mica-topaz aggregate shown in Figure 1 were studied in detail. The aggregate was originally huge, at least $30 \mathrm{~cm}$

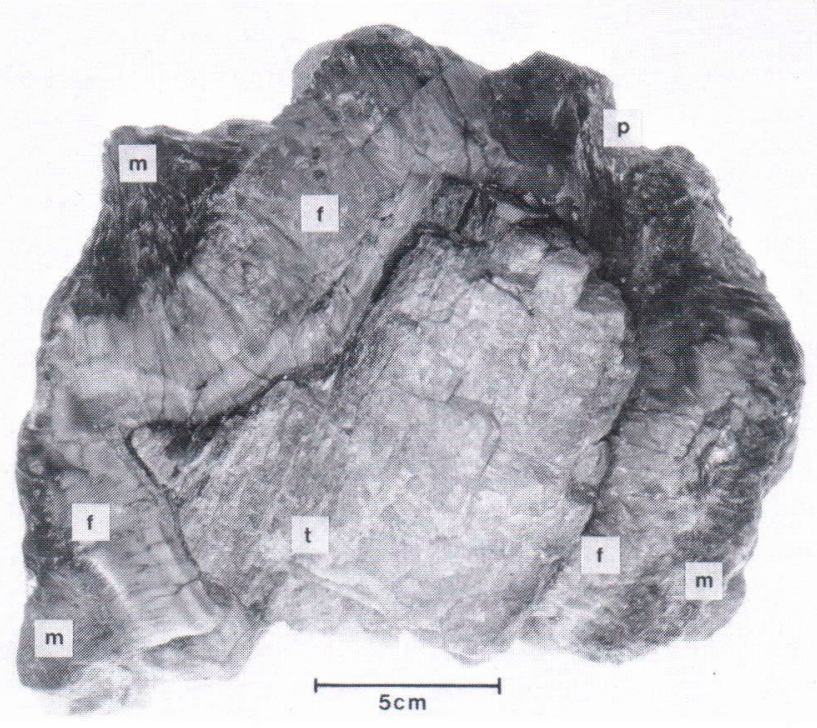

Fig. 1. A typical topaz-mica aggregate from the Juurakko pegmatite. The topaz crystal ( $\mathrm{t}$ ) inside the aggregate is surrounded by a zone of fine-scaled or fibrous, white margarite (f) and very fine-scaled, light-brown muscovite (m). The aggregate is rimmed by coarse-scaled pink or lilac Mn-bearing muscovite (p). 
Table 1. Chemical analyses of a homogeneous mica aggregate (sample no. 1, analyses 1-4) and of a zoned mica-topaz aggregate (sample no. 2, analyses 5-18). Microprobe determinations by Bo Johanson (nos. 1-4 and 17-18), by Seppo Sivonen (nos. 4-5 and 7-16) and ICP analysis by Eeva Kallio (no. 6). Fluorine, water and lithium analysed separately by Risto Saikkonen. - not determined.

\begin{tabular}{|c|c|c|c|c|c|c|c|c|c|c|c|c|c|c|c|c|c|c|}
\hline & 1 & 2 & 3 & 4 & 5 & 6 & 7 & 8 & 9 & 10 & 11 & 12 & 13 & 14 & 15 & 16 & 17 & 18 \\
\hline $\mathrm{SiO}_{2}$ & 47.70 & 48.20 & 49.20 & 48.20 & 32.93 & 32.13 & 32.67 & 31.20 & 31.55 & 45.67 & $45.03-46.66$ & 45.09 & 45.03 & 46.66 & 45.79 & 46.33 & 47.60 & 48.10 \\
\hline $\mathrm{TiO}_{2}$ & 0.00 & 0.00 & 0.00 & 0.00 & 0.01 & 0.01 & 0.00 & 0.00 & 0.00 & 0.00 & $0.00-0.01$ & 0.00 & 0.00 & 0.00 & 0.04 & 0.00 & 0.00 & 0.00 \\
\hline $\mathrm{Al}_{2} \mathrm{O}_{3}$ & 38.10 & 37.40 & 38.10 & 38.20 & 53.01 & 50.37 & 47.12 & 50.72 & 49.97 & 37.50 & $36.69-38.22$ & 37.04 & 36.69 & 38.01 & 36.99 & 37.52 & 38.40 & 38.50 \\
\hline FeOtot. & 0.43 & 0.41 & 0.06 & 0.03 & 0.01 & 0.10 & 0.06 & 0.12 & 0.04 & 0.39 & $0.30-0.57$ & 0.35 & 0.57 & 0.34 & 0.61 & 0.45 & 0.07 & 0.10 \\
\hline $\mathrm{MnO}$ & 0.07 & 0.12 & 0.93 & 0.31 & 0.01 & 0.01 & 0.01 & 0.00 & 0.00 & 0.03 & $0.01-0.05$ & 0.01 & 0.05 & 0.03 & 0.08 & 0.05 & 0.30 & 0.18 \\
\hline $\mathrm{MgO}$ & 0.00 & 0.00 & 0.00 & 0.00 & 0.00 & 0.02 & 0.01 & 0.00 & 0.00 & 0.01 & $0.00-0.04$ & 0.01 & 0.04 & 0.00 & 0.07 & 0.01 & 0.00 & 0.00 \\
\hline $\mathrm{CaO}$ & 0.01 & 0.00 & 0.00 & 0.01 & 0.01 & 9.85 & 8.18 & 8.98 & 7.97 & 0.02 & $0.00-0.05$ & 0.00 & 0.05 & 0.00 & 0.02 & 0.01 & 0.00 & 0.02 \\
\hline $\mathrm{Na}_{2} \mathrm{O}$ & 0.46 & 0.46 & 0.47 & 0.58 & 0.02 & 2.31 & 2.10 & 2.59 & 3.02 & 0.38 & $0.33-0.45$ & 0.33 & 0.45 & 0.43 & 0.48 & 0.35 & 0.52 & 0.49 \\
\hline $\mathrm{K}_{2} \mathrm{O}$ & 10.70 & 10.60 & 9.26 & 10.50 & 0.02 & 0.53 & 1.28 & 0.04 & 0.31 & 9.81 & $9.43-10.25$ & 10.25 & 9.89 & 9.53 & 9.73 & 9.95 & 10.00 & 9.92 \\
\hline $\mathrm{Li}_{2} \mathrm{O}$ & - & - & - & - & - & 0.36 & - & - & - & - & - & - & - & - & - & - & - & - \\
\hline $\mathrm{H}_{2} \mathrm{O}+$ & - & - & - & - & 0.04 & 4.29 & - & - & - & 4.74 & - & - & - & - & - & - & 4.48 & - \\
\hline $\mathrm{F}$ & - & - & - & - & 18.17 & 0.72 & - & - & - & 0.06 & - & - & - & - & - & - & 0.32 & - \\
\hline Total & 97.47 & 97.19 & 98.02 & 97.83 & $\begin{array}{r}104.23 \\
96.58\end{array}$ & $\begin{array}{l}100.70 \\
100.40\end{array}$ & 91.43 & 93.64 & 92.86 & $\begin{array}{l}98.61 \\
98.59\end{array}$ & & 93.08 & 92.75 & 94.98 & 93.80 & 94.68 & $\begin{array}{l}101.69 \\
101.55\end{array}$ & 97.31 \\
\hline $\mathrm{Si}$ & 6.16 & 6.23 & 6.26 & 6.18 & 4.19 & 4.23 & 4.48 & 4.18 & 4.25 & 6.07 & $6.08-6.14$ & 6.09 & 6.10 & 6.14 & 6.13 & 6.14 & 6.16 & 6.18 \\
\hline $\mathrm{Al}^{(\mathrm{IV})}$ & 1.84 & 1.77 & 1.74 & 1.82 & & 3.77 & 3.52 & 3.82 & 3.75 & 1.93 & $1.86-1.92$ & 1.91 & 1.90 & 1.86 & 1.87 & 1.86 & 1.84 & 1.82 \\
\hline $\mathrm{Al}^{(\mathrm{VI})}$ & 3.95 & 3.93 & 3.97 & 3.96 & 7.95 & 4.07 & 4.10 & 4.18 & 4.20 & 3.94 & $3.97-4.04$ & 3.99 & 3.97 & 4.03 & 3.96 & 3.99 & 4.01 & 4.00 \\
\hline $\mathrm{Ti}$ & 0.00 & 0.00 & 0.00 & 0.00 & 0.00 & - & 0.00 & 0.00 & 0.00 & 0.00 & 0.00 & 0.00 & 0.00 & 0.00 & 0.00 & 0.00 & 0.00 & 0.00 \\
\hline $\mathrm{Fe}$ & 0.05 & 0.04 & 0.01 & 0.00 & 0.00 & 0.01 & 0.01 & 0.01 & 0.00 & 0.04 & $0.03-0.06$ & 0.04 & 0.06 & 0.04 & 0.07 & 0.05 & 0.01 & 0.01 \\
\hline Mn & 0.01 & 0.01 & 0.10 & 0.03 & 0.00 & - & 0.00 & 0.00 & 0.00 & 0.00 & 0.00 & 0.00 & 0.01 & 0.00 & 0.01 & 0.01 & 0.03 & 0.02 \\
\hline $\mathrm{Mg}$ & 0.00 & 0.00 & 0.00 & 0.00 & 0.00 & - & 0.00 & 0.00 & 0.00 & 0.00 & $0.00-0.01$ & 0.00 & 0.01 & 0.00 & 0.01 & 0.00 & 0.00 & 0.00 \\
\hline $\mathrm{Li}$ & - & - & - & - & & 0.19 & - & - & - & - & - & - & - & - & - & - & - & - \\
\hline$\Sigma Y$ & 4.01 & 3.99 & 4.08 & 4.00 & & 4.27 & 4.11 & 4.19 & 4.21 & 3.98 & $4.03-4.08$ & 4.03 & 4.04 & 4.07 & 4.04 & 4.05 & 4.07 & 4.04 \\
\hline $\mathrm{Ca}$ & 0.00 & 0.00 & 0.00 & 0.00 & 0.00 & 1.39 & 1.20 & 1.29 & 1.15 & 0.00 & $0.00-0.01$ & 0.00 & 0.01 & 0.00 & 0.00 & 0.00 & 0.00 & 0.00 \\
\hline $\mathrm{Na}$ & 0.12 & 0.12 & 0.12 & 0.14 & 0.00 & 0.59 & 0.56 & 0.67 & 0.79 & 0.10 & $0.09-0.12$ & 0.09 & 0.12 & 0.11 & 0.12 & 0.09 & 0.12 & 0.12 \\
\hline $\mathrm{K}$ & 1.76 & 1.75 & 1.50 & 1.72 & 0.00 & 0.09 & 0.22 & 0.01 & 0.05 & 1.66 & $1.60-1.77$ & 1.77 & 1.71 & 1.60 & 1.66 & 1.68 & 1.64 & 1.63 \\
\hline$\Sigma X$ & 1.88 & 1.86 & 1.62 & 1.86 & & 2.07 & 1.99 & 1.97 & 1.99 & 1.76 & $1.71-1.85$ & 1.85 & 1.83 & 1.71 & 1.79 & 1.77 & 1.76 & 1.75 \\
\hline $\mathrm{OH}$ & - & - & - & - & 0.03 & 3.77 & - & - & - & 4.20 & - & - & - & - & - & - & 3.87 & - \\
\hline F & - & - & - & - & 7.32 & 0.30 & - & - & - & 0.03 & - & - & - & - & - & - & 0.13 & - \\
\hline $\mathrm{O}$ & - & - & - & - & 16.65 & 19.93 & - & - & - & 19.77 & - & - & - & - & - & - & 20.00 & - \\
\hline
\end{tabular}

1, 2 = Fine-scaled muscovite, sample $1 \quad 6-9=$ Fibrous margarite, sample 2

$3,4=$ Pink muscovite, sample $1 \quad 10=$ Fine-scaled muscovite, sample 2, mean of 8 analyses

$12-15=$ Fine-scaled muscovite, sample 2

$5=$ Topaz, sample 2

$11=$ Fine-scaled muscovite, sample 2 ,

= Fibrous muscovite, sample 2

$17-18=$ Pink muscovite, sample 2 


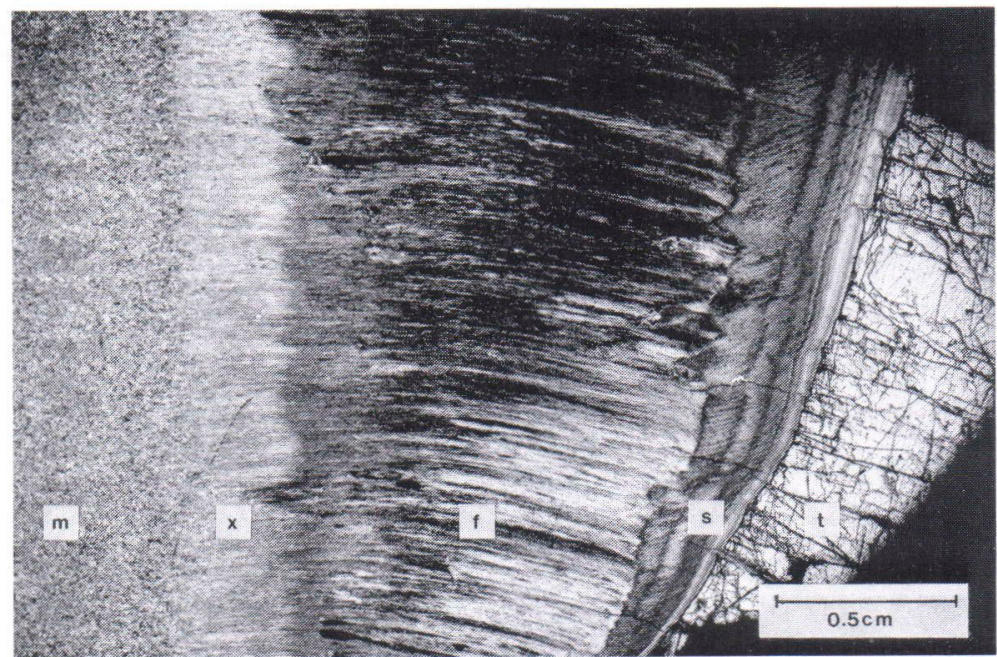

Fig. 2. A detail of the topaz-mica aggregate in Fig. 1. The topaz crystal (t) is surrounded by the zones of finescaled margarite (s), fibrous margarite (f), fine-scaled margarite-muscovite (x) and fine-scaled muscovite (m). The fine-scaled margarite zone against topaz has several subzones differing in colour and grain size. Microphotograph of a thin section, crossed nicols. in diameter. The core of the aggregate consists of a large topaz crystal surrounded and replaced by margarite. The muscovite zone around the topaz-margarite core is composed of an inner, massive, fine-scaled subzone and an outer coarser subzone consisting of pink lepidolite-like muscovite.

The topaz crystal in the core was once more than $15 \mathrm{~cm}$ long and $7 \mathrm{~cm}$ thick. Grey-green in colour, the mineral is columnar in shape and roundish in cross-section. The $\{001\}$ cleavage is distinct. The chemical analysis of the mineral is given in Table 1 (no. 5). The chemical formula of the topaz is nearly ideal. The OES analysis indicates that the mineral is enriched in Ge $(330$ ppm), but the content of the other trace elements is low (Table 4, no. 9).

Margarite occurs as a discontinuous, 1- to 5-cm thick zone around the topaz core. The margarite is fibrous (Fig. 2 and 3), but near the topaz core several thin subzones composed of brownish or greyish, very fine-grained massive margarite (scales $<0.01 \mathrm{~mm}$ long) can be seen.

The margarite fibres have grown perpendicular to the topaz core (Fig. 2). X-ray studies carried out with the precession method showed that generally the a-axis, and less frequently the b-axis, of the mica lies parallel to the fibre axis. The mica crystals in the fibres are very thin (Fig. 3) and rotate separately. As a result, detailed measurements of the unit cell dimensions from the single crystal photographs failed. The X-ray powder diffractogram of the mineral closely resembles the one given in JCPDS-card 18-276. The unit cell dimensions computed from the indexed $\mathrm{x}$-ray powder diffraction pattern are: $\mathrm{a}=5.126 \AA, \mathrm{b}=8.885 \AA, \mathrm{c}=19.226 \AA$ and $\beta=$ $95.53^{\circ}$.

Representative microprobe analyses and an ICP-AES analysis of a powdered margarite sample are given in Table 1 (ICP-AES analysis no. 6 and representative microprobe analyses no.

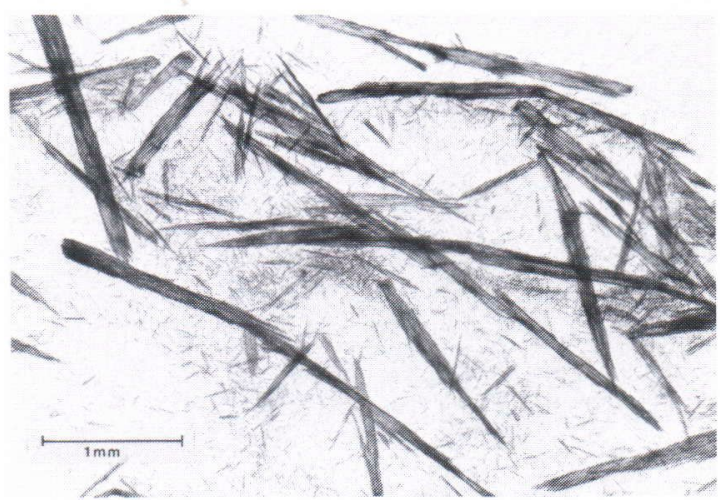

Fig. 3. Microphotograph of crushed fibrous margarite from the pseudomorph after topaz. 
7-9). The chemical formula of the mineral computed from the ICP-AES analysis and separate water and fluorine determinations (see Table 1 , no. 6), and based on $24(\mathrm{O}, \mathrm{OH}, \mathrm{F})$, is:

$$
\left(\mathrm{Ca}_{1.39} \mathrm{Na}_{0.59} \mathrm{~K}_{0.09}\right)\left(\mathrm{Al}_{4.07} \mathrm{Fe}_{0.01} \mathrm{Li}_{0.19}\right)\left(\mathrm{Si}_{4.23} \mathrm{Al}_{3.77}\right)\left(\mathrm{OH}_{3.77} \mathrm{~F}_{0.30}\right) \mathrm{O}_{19.93}
$$

The chemical formula of the Juurakko margarite differs slightly from that of an ideal dioctahedral margarite, and the mica has prominent $\mathrm{Na}\left(2.31 \mathrm{wt} \% \mathrm{Na}_{2} \mathrm{O}\right), \mathrm{Li}\left(0.36 \mathrm{wt} \% \mathrm{Li}_{2} \mathrm{O}\right)$, and $\mathrm{F}(0.72 \mathrm{wt} \% \mathrm{~F})$. Na, which replaces interlayered $\mathrm{Ca}$ in the margarite structure, shows marked variation from one crystal to another; the range of the $\mathrm{Na} /(\mathrm{Na}+\mathrm{Ca})$ ratio varies between 0.32 and 0.41 . The trace elements are given in Table 4 (no. 1). The mica shows high concentrations of $\mathrm{Be}$ (255 ppm), Sr (118 ppm) and B (88 ppm).

Fine-scaled massive muscovite forms a shell around the margarite zone. The colour of the mica is light brown or grey. The muscovite zone is $1-5 \mathrm{~cm}$ thick but contains several subzones differing in colour. The mica scales are only $0.01-0.05 \mathrm{~mm}$ long.

Microprobe analyses of the muscovite are given in Table 1 (no. 10: mean of analyses; no. 11: the range, nos. $12-15$ representative analyses). The muscovite is nearly ideal in formula, although the combination of the mean of the microprobe data and the separate fluorine and water determinations indicates some excess in the $\mathrm{OH}+\mathrm{F} /$ formula unit. The sum of the interlayer

$$
\left(\mathrm{K}_{1.64} \mathrm{Na}_{0.12}\right)
$$

The trace elements of the mica are shown in Table 4 (no. 7).

\section{Columnar mica pseudomorphs after topaz}

Several columnar mica pseudomorphs with either poorly- or well-developed crystal form resembling that of topaz were encountered in the pegmatite. Some examples are shown in Figure 4. The cross-section of the pseudomorphs is a square or oblique square. The prism faces are usually $\{110\}$ faces of the altered topaz crystals, although combinations of $\{110\}$ and $\{120\}$ faces cations ranges from 1.66 to $1.85 / \mathrm{O}_{20}(\mathrm{OH}, \mathrm{F})_{4}$, and the mica is low in $\mathrm{Na}(\mathrm{Na} /(\mathrm{Na}+\mathrm{K})=0.05-$ $0.07)$ and $\mathrm{Fe}(\mathrm{FeO} 0.30-0.57 \mathrm{wt} \%)$. The trace elements are listed in Table 4 (no. 3).

Fibrous muscovite occurs as a small accumulation between the margarite and surrounding massive muscovite in one part of the specimen. Chemical analysis shows that the mica is nearly ideal dioctahedral muscovite (Table 1, no. 16) and resembles the fine-scaled muscovite in composition.

Pink flaky muscovite occurs as a discontinuous zone around the aggregate. The mica flakes are $5-30 \mathrm{~mm}$ in diameter. The pink or lilac colour closely resembles that of lepidolite, and the minerals are difficult to distinguish without chemical and $\mathrm{x}$-ray studies. The chemical analyses (Table 1, no. 17-18) indicate that the muscovite is nearly ideally dioctahedral in composition. It has minor concentrations of Mn (up to 0.3 wt \% $\mathrm{MnO})$ and the mica is poor in $\mathrm{Fe}(\mathrm{Mn} / \mathrm{Fe}$ $=2-4)$. The chemical formula computed on the basis of $24(\mathrm{O}, \mathrm{OH}, \mathrm{F})$ from the combined microprobe analyses and separate water and fluorine determinations is:

$\left(\mathrm{Al}_{4.01} \mathrm{Mn}_{0.03} \mathrm{Fe}_{0.01}\right)\left(\mathrm{Al}_{1.84} \mathrm{Si}_{6.16}\right)(\mathrm{OH})_{3.87} \mathrm{~F}_{0.13} \mathrm{O}_{20.00}$

can be recognized in some pseudomorphs. The pyramidal faces are usually deformed.

The pseudomorphs vary widely in size being $1-5 \mathrm{~cm}$ in diameter and up to $15 \mathrm{~cm}$ long. Sometimes they are closely associated with mica aggregates. The long prismatic form and the crosssection of the pseudomorphs also resemble the form of andalusite crystals. Although andalusite may occur in pegmatites, the mineral has not been found in the pegmatite dykes of the area, and the pseudomorphs are considered those after long prismatic topaz crystals.

The pseudomorphs may be homogeneous or zoned like the mica aggregates. The homogene- 


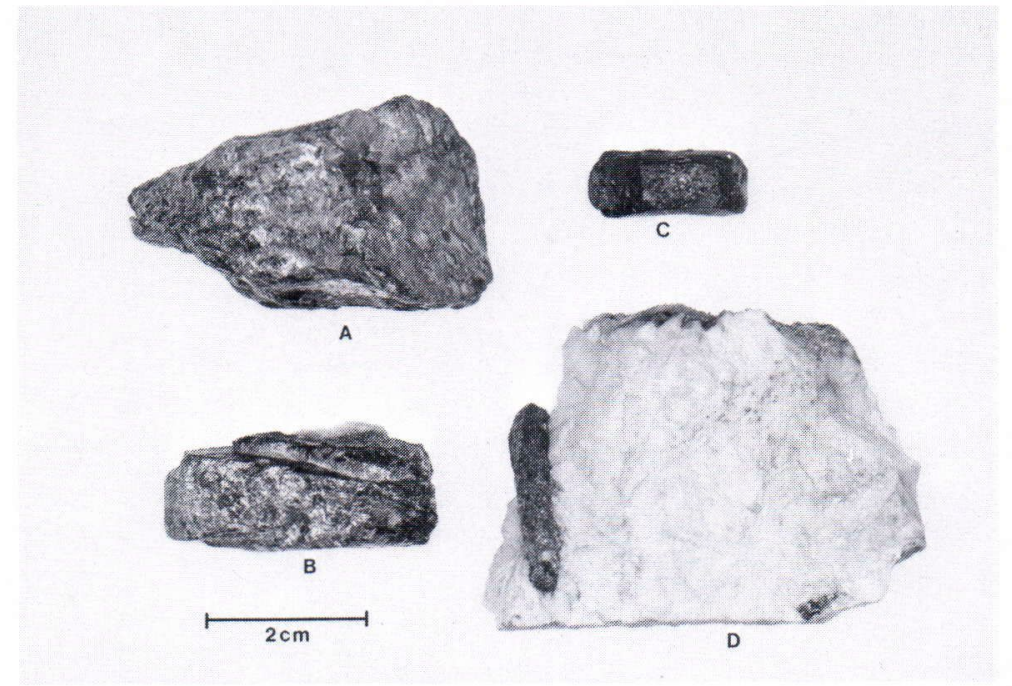

Fig. 4. Columnar mica pseudomorphs after topaz crystals. Pseudomorphs A and $\mathrm{B}$ are zoned and composed of a very fine-scaled margarite-muscovite core surrounded by an outer muscovite shell. Pseudomorphs $\mathrm{C}$ and $\mathrm{D}$ are homogeneous and consist only of very fine-scaled muscovite. ous pseudomorphs are composed of very finescaled massive muscovite, whereas the zoned pseudomorphs contain a margarite-bearing core and may have some concentrically alternating margarite and muscovite zones; remnants of topaz have not been observed.

\section{Mineralogy of a homogeneous mica pseudomorph}

The homogeneous pseudomorph studied in detail is about $15 \mathrm{~cm}$ long, and the faces, being originally $\{110\}$ faces of a topaz crystal, are about $4 \mathrm{~cm}$ wide. The pseudomorph has tapering terminations and uneven prism faces. The mica scales are $0.05-0.10 \mathrm{~mm}$ long in the middle of the pseudomorph, but the rim is coarse-scaled.

The microprobe analyses of the muscovite are shown in Table 2 (no. 1: mean of analyses, no. 2: ranges, nos. $3-5$ representative analyses) and the trace elements in Table 4 (no. 5). The analytical results indicate that the muscovite would be ideally dioctahedral in composition, if the sum of the interlayer cations, $1.61-1.81$, were not so low. The content of minor elements $\mathrm{Fe}$ and $\mathrm{Na}$ is minute.

\section{Mineralogy of a zoned mica pseudomorph}

The zoned pseudomorph studied in detail was originally about $12 \mathrm{~cm}$ long (Fig. $4 \mathrm{~A}$ ), and it is nearly a square in cross-section. The original (110) faces of the topaz crystal are well preserved, although uneven. The pyramidal faces are strongly deformed.

Figure 5 shows two polished sections of the pseudomorph. The core is composed of a finescaled margarite-muscovite mixture surrounded by an irregular, white margarite zone and muscovite zones. The margarite zone has several undulating subzones. The microprobe analyses indicate that also kaolinite, too, may occur with the micas, but the mineral could not be identified with x-ray powder diffraction. Some parts of the outer main muscovite zone are fibrous, and the muscovite fibres are perpendicular to the surface of the pseudomorph.

Muscovite is a massive, very fine-scaled (the scales $0.001-0.005 \mathrm{~mm}$ long), brownish yellow mineral. The main elements of the mica are shown in Table 2 (nos. 10-12) and the trace elements in Table 4 (no. 2). The analytical data indicate that the composition of muscovite does not vary much between the zones. The mica is near- 
Table 2. Chemical analyses of micas from a homogeneous columnar mica pseudomorph (sample no. 3, analyses $1-5$ ) and from a columnar zoned mica pseudomorph (sample no. 4, analyses 6-12). Microprobe determinations by Seppo Sivonen. - not determined.

\begin{tabular}{|c|c|c|c|c|c|c|c|c|c|c|c|c|}
\hline & 1 & 2 & 3 & 4 & 5 & 6 & 7 & 8 & 9 & 10 & 11 & 12 \\
\hline $\mathrm{SiO}_{2}$ & 47.37 & $46.11-47.93$ & 46.74 & 47.65 & 47.12 & 32.55 & 31.21 & 30.42 & 30.52 & 46.20 & 45.18 & 46.04 \\
\hline $\mathrm{TiO}_{2}$ & 0.01 & $0.00-0.02$ & 0.00 & 0.02 & 0.00 & 0.00 & 0.00 & 0.00 & 0.01 & 0.00 & 0.00 & 0.01 \\
\hline $\mathrm{Al}_{2} \mathrm{O}_{3}$ & 38.28 & $37.50-38.81$ & 37.98 & 38.43 & 37.50 & 48.42 & 49.15 & 48.62 & 49.78 & 39.27 & 37.44 & 37.81 \\
\hline FeOtot. & 0.57 & $0.43-0.72$ & 0.43 & 0.58 & 0.71 & 0.07 & 0.09 & 0.10 & 0.09 & 0.25 & 0.31 & 0.29 \\
\hline $\mathrm{MnO}$ & 0.02 & $0.00-0.04$ & 0.00 & 0.03 & 0.04 & 0.00 & 0.01 & 0.00 & 0.00 & 0.00 & 0.00 & 0.01 \\
\hline $\mathrm{MgO}$ & 0.02 & $0.00-0.08$ & 0.00 & 0.00 & 0.08 & 0.00 & 0.01 & 0.00 & 0.00 & 0.00 & 0.02 & 0.02 \\
\hline $\mathrm{CaO}$ & 0.02 & $0.00-0.05$ & 0.00 & 0.01 & 0.02 & 10.43 & 10.04 & 9.73 & 9.47 & 0.02 & 0.01 & 0.04 \\
\hline $\mathrm{Na}_{2} \mathrm{O}$ & 0.47 & $0.29-0.62$ & 0.62 & 0.45 & 0.37 & 1.57 & 2.01 & 2.09 & 2.31 & 0.52 & 0.34 & 0.39 \\
\hline $\mathrm{K}_{2} \mathrm{O}$ & 9.46 & $8.99-10.04$ & 9.69 & 9.07 & 9.71 & 0.26 & 0.22 & 0.19 & 0.03 & 9.51 & 9.73 & 9.89 \\
\hline $\mathrm{Li}_{2} \mathrm{O}$ & - & - & - & - & - & - & - & - & - & - & - & - \\
\hline $\mathrm{H}_{2} \mathrm{O}+$ & - & - & - & - & - & - & - & - & - & - & - & - \\
\hline \multirow[t]{2}{*}{$\mathrm{F}$} & - & - & - & - & - & - & - & - & - & - & - & - \\
\hline & 96.22 & & 95.45 & 96.24 & 95.55 & 93.30 & 92.73 & 91.14 & 92.22 & 95.77 & 93.02 & 94.49 \\
\hline $\mathrm{Si}$ & 6.15 & $6.05-6.19$ & 6.13 & 6.17 & 6.18 & 4.38 & 4.23 & 4.20 & 4.16 & 6.03 & 6.08 & 6.10 \\
\hline $\mathrm{Al}^{(\mathrm{IV})}$ & 1.85 & $1.81-1.95$ & 1.87 & 1.83 & 1.82 & 3.62 & 3.77 & 3.80 & 3.84 & 1.97 & 1.92 & 1.90 \\
\hline $\mathrm{Al}^{(\mathrm{VI})}$ & 4.01 & $3.97-4.03$ & 4.00 & 4.03 & 3.97 & 4.05 & 4.09 & 4.10 & 4.15 & 4.07 & 4.03 & 4.01 \\
\hline $\mathrm{Ti}$ & 0.00 & 0.00 & 0.00 & 0.00 & 0.00 & 0.00 & 0.00 & 0.00 & 0.00 & 0.00 & 0.00 & 0.00 \\
\hline $\mathrm{Fe}$ & 0.06 & $0.05-0.08$ & 0.05 & 0.06 & 0.08 & 0.01 & 0.01 & 0.01 & 0.01 & 0.03 & 0.04 & 0.03 \\
\hline Mn & 0.00 & 0.00 & 0.00 & 0.00 & 0.00 & 0.00 & 0.00 & 0.00 & 0.00 & 0.00 & 0.00 & 0.00 \\
\hline $\mathrm{Mg}$ & 0.00 & $0.00-0.02$ & 0.00 & 0.00 & 0.01 & 0.00 & 0.00 & 0.00 & 0.00 & 0.00 & 0.00 & 0.00 \\
\hline $\mathrm{Li}$ & - & - & - & - & - & - & - & - & - & - & - & - \\
\hline$\Sigma \mathrm{Y}$ & 4.07 & $4.05-4.09$ & 4.05 & 4.10 & 4.05 & 4.05 & 4.09 & 4.10 & 4.15 & 4.10 & 4.06 & 4.05 \\
\hline $\mathrm{Ca}$ & 0.00 & $0.00-0.01$ & 0.00 & 0.00 & 0.00 & 1.50 & 1.46 & 1.44 & 1.38 & 0.00 & 0.00 & 0.01 \\
\hline $\mathrm{Na}$ & 0.12 & $0.07-0.16$ & 0.16 & 0.11 & 0.09 & 0.41 & 0.53 & 0.56 & 0.61 & 0.13 & 0.09 & 0.10 \\
\hline K & 1.56 & $1.48-1.68$ & 1.62 & 1.50 & 1.62 & 0.04 & 0.04 & 0.03 & 0.01 & 1.58 & 1.67 & 1.67 \\
\hline$\Sigma X$ & 1.68 & $1.61-1.81$ & 1.78 & 1.61 & 1.72 & 1.96 & 2.03 & 2.03 & 2.00 & 1.71 & 1.76 & 1.77 \\
\hline $\mathrm{OH}$ & - & - & - & - & - & - & - & - & - & - & - & - \\
\hline $\mathrm{F}$ & - & - & - & - & - & - & - & - & - & - & - & - \\
\hline $\mathrm{O}$ & - & - & - & - & - & - & - & - & - & - & - & - \\
\hline
\end{tabular}

$1=$ Fine-scaled muscovite, sample 3, mean of 9 analyses

$2=$ Fine-scaled muscovite, sample 3, ranges of 9 analyses $3-5$ = Fine-scaled muscovite, sample 3
$6-9=$ Fine-scaled margarite, sample 4 $10-12=$ Fine-scaled muscovite, sample 4 ly ideally dioctahedral in composition, and the ranges of the interlayer cations are from 1.71 to $1.77 / \mathrm{O}_{20}(\mathrm{OH}, \mathrm{F})_{4}$. The muscovite is poor in $\mathrm{Na}$ and very low in Fe.

Margarite is very fine-scaled like muscovite, but the colour is white. The microprobe analyses of the mica are given in Table 2 (no. 6-9). The composition of this margarite closely resembles that of the zoned topaz-margarite pseudomorph described above. The mica is, however, less sodic; the $\mathrm{Na} /(\mathrm{Na}+\mathrm{Ca})$ ratio is between 0.21 and 0.31 .

Because the margarite is very fine-scaled and intergrown with muscovite, separation of the mineral failed. The OES analysis was based on a margarite powder probably containing 10$20 \%$ muscovite. The analytical results show only 700 ppm Li and 40 ppm Be (Table 4, anal. 2), indicating that the margarite is poorer in these elements than is the fibrous margarite from the mica-topaz aggregate described above. 


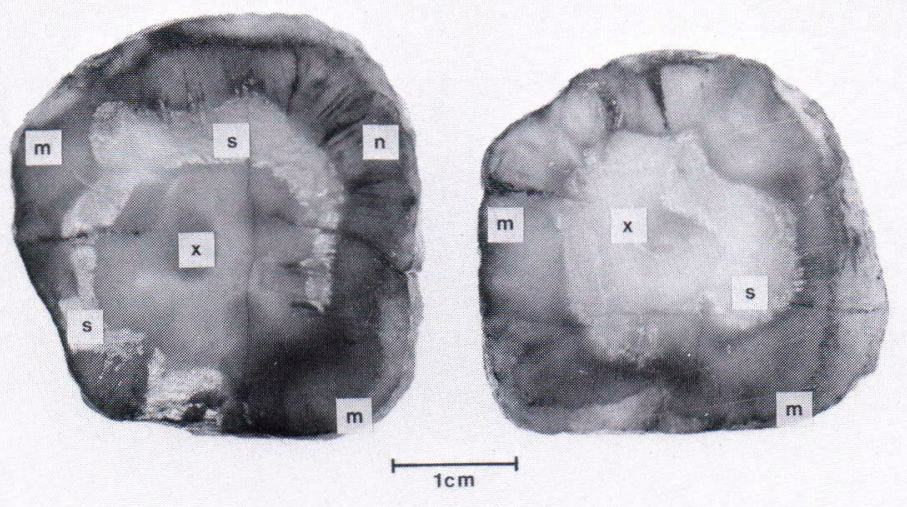

Fig. 5. Two polished sections of the margarite-muscovite pseudomorph presented in Fig. 4A. The core is composed of a fine-scaled margaritemuscovite mixture (x) surrounded by a white irregular zone of fine-scaled margarite (s) and fine-scaled muscovite (m) or fibrous muscovite (n). The black radiating stripes are graphite.

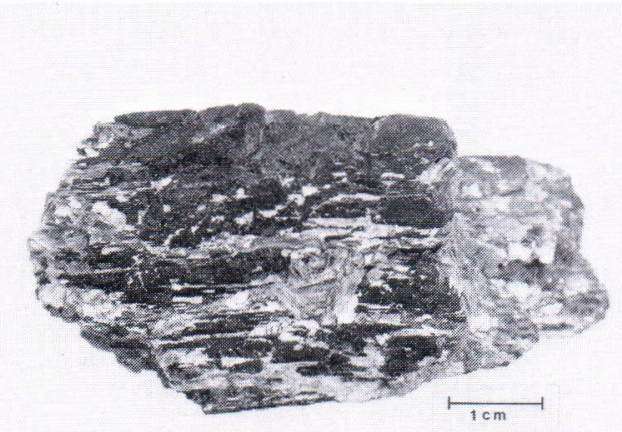

Fig. 6. A piece of tourmaline crystal replaced by phengitic muscovite (white).

\section{Comparison with other mica pseudomorphs}

\section{Mica pseudomorphs after tourmaline}

The tourmaline (schorl) crystals occurring in the intermediate zone, albite-rich fracture fillings and replacement bodies are often partially replaced by fine-scaled muscovite (Fig. 6). Totally altered crystals are, however, rare, and the mica pseudomorphs often have a schorl core or small corroded inclusions of schorl.

The pseudomorphs are usually $0.5-3.0 \mathrm{~cm}$ in diameter and several centimetres long. The original hexagonal cross-section and the prismatic form of the tourmaline crystals may be well preserved in the pseudomorphs. The muscovite scales are yellowish in colour. The mica is usually coarser than in the pseudomorphs after topaz.

Two columnar mica pseudomorphs about $3 \mathrm{~cm}$ in diameter and several centimetres long, both of them consisting mainly of fine-scaled (scales 0.2-2.0 mm long), yellowish muscovite, were studied. Corroded fragments of black tourmaline are common in one of the pseudomorphs. The cross-sections of the pseudomorphs are roundish or partly triangular. The prismatic faces are uneven and the terminations irregular.

Table 3 (sample 5, nos. 1-4 and sample 6, nos. 5-9) gives the chemical composition of muscovite from both pseudomorphs. The formula of the mica computed on the basis of 24 $(\mathrm{O}, \mathrm{OH}, \mathrm{F})$ from the mean of the microprobe analyses and separate fluorine and water determinations (Table 3, no. 5) is:

$$
\left(\mathrm{K}_{1.67} \mathrm{Na}_{0.03}\right)\left(\mathrm{Al}_{3.69} \mathrm{Fe}_{0.31} \mathrm{Mn}_{0.05} \mathrm{Mg}_{0.04} \mathrm{Ti}_{0.01}\right)\left(\mathrm{Si}_{6.34} \mathrm{Al}_{1.66}\right)(\mathrm{OH})_{3.70} \mathrm{~F}_{0.28} \mathrm{O}_{20.02}
$$


Table 3. Chemical analyses of fine-scaled muscovite from two pseudomorphs after tourmaline (sample no. 5, analyses $1-4$ and sample no. 6, analyses 5-9) and of a pseudomorph after garnet (sample no. 7, analyses 10 and 11). Microprobe determinations by Seppo Sivonen (nos. 1-9) and Bo Johanson (10 and 11). Fluorine and water analysed separately by Risto Saikkonen. - not determined.

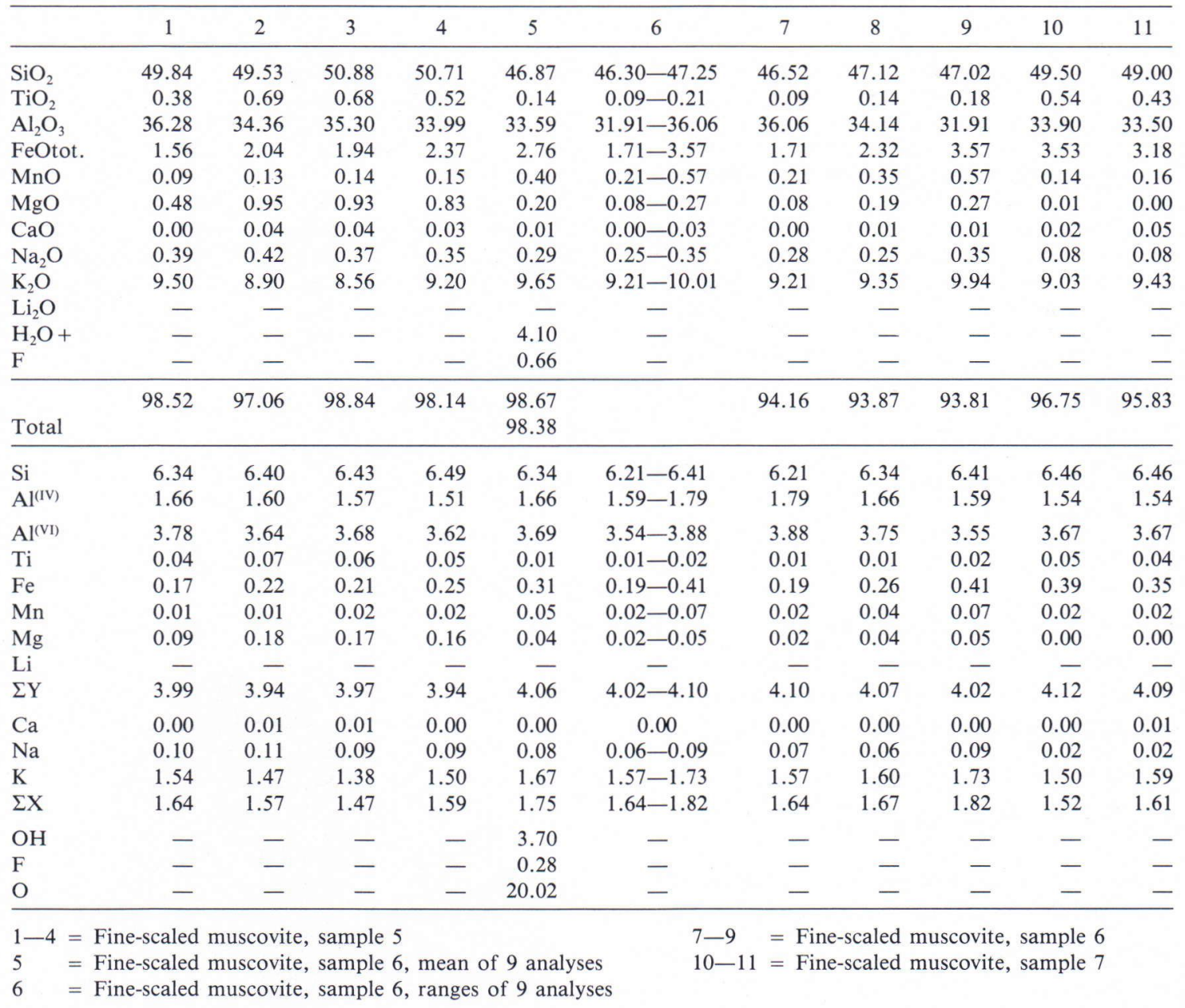

The micas have prominent $\mathrm{Fe}, \mathrm{Mg}, \mathrm{Mn}$ and $\mathrm{Ti}$, the range of the sum of these elements being $0.23-0.53$ per $\mathrm{O}_{20}(\mathrm{OH}, \mathrm{F})_{4}$. The sum of the interlayer cations is very low (in the range 1.47$\left.1.64 / \mathrm{O}_{20}(\mathrm{OH})_{4}\right)$. The trace elements determined from one of the specimens are listed in Table 4 (no. 8).

\section{Mica-bearing pseudomorphs after beryl}

The beryl occurring in the intermediate zone is fresh but in fracture fillings and albite-rich replacement units it is often altered. The size of the pseudomorphs varies widely. Some of the beryl crystals are huge being $10-30 \mathrm{~cm}$ in diameter, and partially altered. However, the smaller crystals may be totally altered and filled with replacement and alteration products.

Platy, colourless bertrandite is often a main mineral in the pseudomorphs (see Lahti 1981), but porous pseudomorphs composed of massive chlorite-bertrandite-muscovite intergrowth are also common. The colour of the mica intergrowths is greyish or brownish when stained with 
Table 4. The trace and minor elements (ppm) in topaz (9) and in the micas of the pseudomorphs after topaz (1-7) and tourmaline (8). ICP-AES analyses x (by Eeva Kallio), OES analyses • (by Christian Backman) and AAS analyses + (by Risto Saikkonen) and XRF analyses * (by V. Hoffren). - not observed.

\begin{tabular}{|c|c|c|c|c|c|c|c|c|c|}
\hline & 1 & 2 & 3 & 4 & 5 & 6 & 7 & 8 & 9 \\
\hline B & $88 \bullet$ & $80 \bullet$ & $100 \bullet$ & $72 \bullet$ & $37 \bullet$ & $>300^{\bullet}$ & & $140 \bullet$ & $<20 \bullet$ \\
\hline $\mathrm{Li}$ & $1700+$ & $700 \bullet$ & $443+$ & $370+$ & $430+$ & $300+$ & $250+$ & $1025+$ & $<500 \bullet$ \\
\hline $\mathrm{Rb}$ & $5+$ & $830 *$ & $1080+$ & $1650+$ & $1200+$ & $2230+$ & $2070+$ & $1790+$ & \\
\hline $\mathrm{Cs}$ & - & & - & $120+$ & $89+$ & $1740+$ & $1400+$ & $120+$ & \\
\hline $\mathrm{Be}$ & $255+$ & $40 \bullet$ & $63+$ & $6 \bullet$ & $14 \bullet$ & $13 \bullet$ & $25+$ & $16+$ & $<5 \bullet$ \\
\hline $\mathrm{Sr}$ & $118+$ & $60 *$ & $32+$ & $15 \bullet$ & $18 \bullet$ & $19 \bullet$ & $8+$ & $8+$ & \\
\hline $\mathrm{Ba}$ & $18 \mathrm{x}$ & $20 *$ & $150 \mathrm{x}$ & $20 x$ & $71 x$ & $13 x$ & $23 x$ & $64 x$ & $18 \bullet$ \\
\hline $\mathrm{Sn}$ & & & $400 *$ & $400 *$ & $500 *$ & $500 *$ & $400 *$ & $900 *$ & - \\
\hline $\mathrm{Mn}$ & $68 x$ & $300 \bullet$ & $159 x$ & $638 x$ & $208 x$ & $1799 x$ & $1124 x$ & $1187 x$ & $10 x$ \\
\hline $\mathrm{Cu}$ & $10 x$ & & $6 x$ & $57 x$ & $12 \mathrm{x}$ & $327 x$ & $3 x$ & $18 \mathrm{x}$ & $5 x$ \\
\hline $\mathrm{Zn}$ & $80 x$ & & $28 x$ & $75 x$ & $51 x$ & $110 x$ & $51 x$ & $117 x$ & $10 \mathrm{x}$ \\
\hline $\mathrm{Ga}$ & $15 \bullet$ & $38 \bullet$ & $30 \bullet$ & $90 \bullet$ & $38 \bullet$ & $100 \bullet$ & $66 \bullet$ & $>100 \bullet$ & $<10^{\bullet}$ \\
\hline $\mathrm{Ni}$ & $32 x$ & $<20$ & $19 x$ & $6 x$ & $10 x$ & $12 \mathrm{x}$ & $25 x$ & $19 x$ & $32 x$ \\
\hline
\end{tabular}

1. Fibrous margarite, sample no. 2

2. Margarite + Muscovite, sample no. 4

3. Fine-scaled muscovite, sample no. 4

4. Fine-scaled muscovite, sample no. 1

5. Fine-scaled muscovite, sample no. 3

iron hydroxides. Similar pseudomorphs after beryl have been described by Roering and Heckroodt (1972) from the Dernburg pegmatite, Karibib, South West Africa.

\section{Mica-bearing pseudomorphs after garnet}

Almandine-spessartine garnet has been encountered as an accessory mineral in various parts of the pegmatite. The crystals are euhedral or subhedral, more commonly showing $\{211\}$ faces. The mineral is usually fresh, but during the studies some muscovite pseudomorphs after garnet were encountered in the albite-quartz pegmatite associated with pseudomorphs after beryl, topaz and tourmaline (Fig. 7). The muscovite is fine-scaled, with flakes $0.05-2.0 \mathrm{~mm}$ long and a brown yellow colour. The pseudomorphs do not contain fragments of garnet, but the original crystal form (icositetrahedron) of garnet is often well-preserved.

Two microprobe analyses of the muscovite in a pseudomorph after garnet are given in Table 3 (nos. 10 and 11). The muscovite is rich in
6. Pink muscovite, sample no. 1

7. Pink muscovite, sample no. 2

8. Muscovite, sample no. 5

9. Topaz, sample no. 2

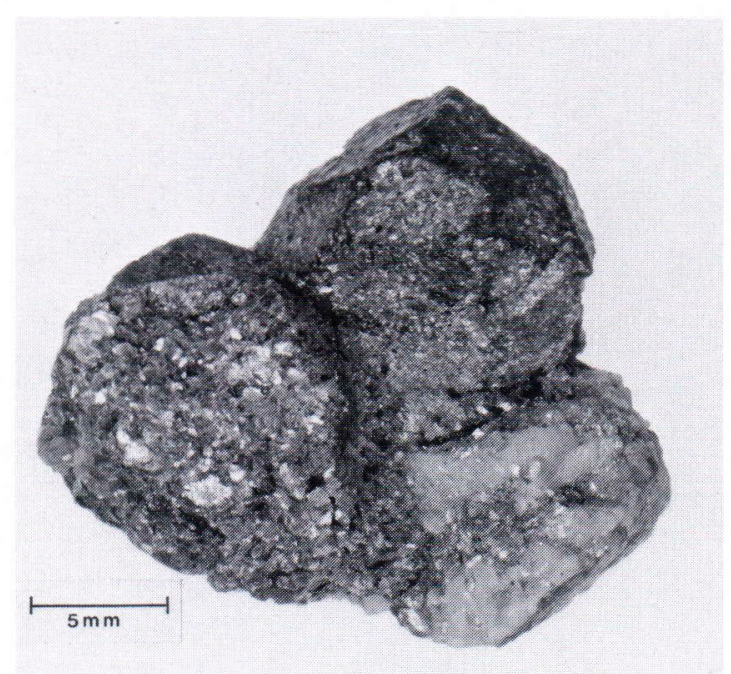

Fig. 7. Two altered garnet crystals from the Juurakko pegmatite. The pseudomorphs contain only fine-scaled phengitic muscovite.

$\mathrm{Fe}$ and $\mathrm{Ti}$ as are the micas in the pseudomorphs after tourmaline, but they contain less $\mathrm{Na}$. The sum of $\mathrm{Fe}, \mathrm{Mn}, \mathrm{Mg}$ and $\mathrm{Ti}$ ranges from 0.41 to 0.46 per $\mathrm{O}_{20}(\mathrm{OH}, \mathrm{F})_{4}$. The $\mathrm{Na} /(\mathrm{Na}+\mathrm{K})$ ratio is 
only 0.01 . The sum of the interlayer cations is very low, being between 1.52 and 1.61 per $\mathrm{O}_{20}(\mathrm{OH}, \mathrm{F})_{4}$.

\section{Discussion}

\section{General alteration trends of topaz in pegmatites}

Several examples of the alteration of topaz to muscovite, clay minerals or paragonite have been described in the literature, although the composition and properties of the micas have rarely been studied in detail. Blue-green topaz crystals are common in the Viitaniemi pegmatite near the Juurakko dyke. The mineral is usually fresh and only rarely replaced by fine-scaled greenish muscovite. Pink muscovite and clay minerals characterize the pseudomorphs after topaz in the Harding pegmatite, New Mexico (Jahns and Ewing 1977) and in the Brown Derby pegmatite, Colorado (Rosenberg 1972). In the Pidlite pegmatite, New Mexico, pink muscovite and paragonite replace topaz crystals (Jahns 1953).

Pink, lilac or rose muscovites, which seem to be common in the pseudomorphs after topaz, are generally very poor in iron, but the micas are enriched in manganese (Heinrich and Levinson 1953). The pseudomorphs may also contain ironrich muscovite or hydromuscovite. Kornetova
(1954) has described phengitic muscovites from a pseudomorph after topaz in a pegmatite of East Baikal, and Marchenko and Polynovskij (1970) have reported their occurrence in the pegmatites of the Ukraine. The fibrous habitus of the mica described by Marchenko and Polynovskij is attributed to tectonic stress accompanying the replacement process. Alteration of topaz, especially in greisens, is common, and the alteration products of topaz are lithium- and iron-rich muscovites or hydromuscovites (Grigorév and Dolomanova 1954, Kelly and Rye 1979).

The alteration of topaz is caused by the supercritical vapour phase released from the pegmatite melt during the final phase of crystallization of the pegmatite dyke. During the break-down processes, aluminium is often incorporated into micas and clay minerals, but the composition of the micas and the crystallization of the other decomposition products are largely dependent on the concentrations of various elements in the fluids and on the physicochemical conditions during the alteration.

Phase diagrams of the stability and subsolidus alteration of topaz have been presented by Burt (1976, 1981), Burt and London (1982) and Barton (1982). According to them, the alteration reaction of topaz to muscovite can be written as follows:

$$
\underset{\text { topaz }}{\mathrm{Al}_{2} \mathrm{SiO}_{4}(\mathrm{~F}, \mathrm{OH})_{2}}+\underset{\text { K-feldspar }}{\mathrm{KAlSi}_{3} \mathrm{O}_{8}}+\underset{\text { muscovite }}{2 \mathrm{H}_{2} \mathrm{O}}=\underset{\text { RAl }}{\mathrm{KAl}_{3} \mathrm{Si}_{3} \mathrm{O}_{10}(\mathrm{~F}, \mathrm{OH})_{2}}+\underset{\text { quartz }}{\mathrm{SiO}_{2}}+2 \mathrm{HF}
$$

The reaction goes to the right on cooling and could produce the very fluorine rich hydrothermal residual fluids and muscovite-quartz greisen type alteration. Fluorite that often occur with the alteration products of aluminosilicates, is a common fluorine buffer in these mineral parageneses.

To the knowledge of the author, this is the first time margarite has been described as an alteration product of topaz. The occurrence of margarite in the Juurakko pegmatite is also restrict- ed to certain parts of the dyke, indicating that $\mathrm{Ca}$ metasomatism was a rather local phenomenon. Because the $\mathrm{Si} / \mathrm{Al}$ ratio in both of the minerals, topaz and margarite, is $1: 2$, only $\mathrm{Ca}$ and $\mathrm{H}_{2} \mathrm{O}$ are needed in the replacement reaction. Analogously to the stability reaction anorthite + aluminosilicate $=$ margarite + quartz + water proposed by Storre and Nitsch (1974), the breakdown reaction of topaz to margarite may be written as follows:

$$
\underset{\text { topaz }}{\mathrm{Al}_{2} \mathrm{SiO}_{4} \mathrm{~F}_{2}}+\underset{\text { anorthite }}{\mathrm{CaAl}_{2} \mathrm{Si}_{2} \mathrm{O}_{8}}+\underset{\text { margarite }}{2 \mathrm{H}_{2} \mathrm{O}}=\underset{\text { quartz }}{\mathrm{CaAl}_{2}\left(\mathrm{Si}_{2} \mathrm{Al}_{2}\right) \mathrm{O}_{10}(\mathrm{OH})_{2}}+\underset{\text { quar }}{\mathrm{SiO}_{2}}+2 \mathrm{HF}
$$


The source of calcium in the hydrothermal fluids may be the plagioclase undergoing subsolidus alteration.

Corroded cores of topaz crystals are typical of the pseudomorphs, but concentric zoning of various micas similar to that in the pseudomorphs of the Juurakko pegmatite has not previously been described to the knowledge of the author. The alternating zones of margarite and muscovite may be a result of diffusion during alteration. The occurrence of discontinuous shells of fibrous margarite around the topaz core may indicate that the mineral crystallized in the crack or in a solution cavity opened between the topaz core and the surrounding muscovite shell. The fibrous appearance is characteristic of minerals crystallized during the opening of fractures of rocks (Grigor'ev 1965, pp. 190-191, Rutstein 1979).

\section{Chemistry of muscovite in the pseudomorphs}

The fine-scaled muscovite analysed from four pseudomorphs after topaz is almost ideally dioctahedral in composition, and the amount of paragonite and phengite components is minute

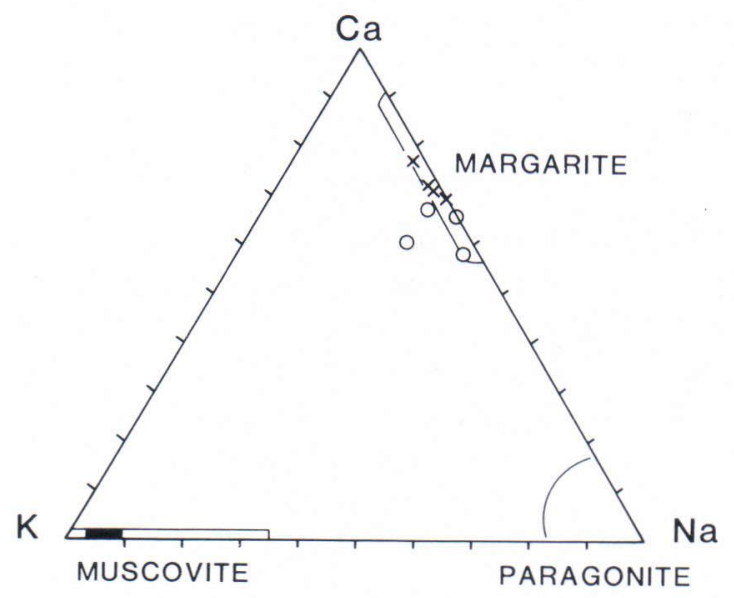

Fig. 8. The analytical data on the Juurakko margarite (rings refer sample no. 2 in Table 1 , crosses refer to sample no. 4 in Table 2) and muscovite (black area near the $\mathrm{K}$ corner) plotted in the $\mathrm{K}-\mathrm{Ca}-\mathrm{Na}$ triangular diagram. The marked areas represent the main composition areas of margarite, muscovite and paragonite according to Frey et al. (1982). (see Fig. 8). Replacement of $\mathrm{K}$ by $\mathrm{Na}$ or $\mathrm{Ca}$ and octahedral $\mathrm{Al}$ by $\mathrm{Fe}, \mathrm{Mn}, \mathrm{Mg}$ and $\mathrm{Li}$ is slight. $\mathrm{The} \mathrm{Na} /(\mathrm{Na}+\mathrm{K})$ ratio and the sum of $\mathrm{Fe}, \mathrm{Mg}$, $\mathrm{Mn}$ and $\mathrm{Ti} / \mathrm{O}_{20}(\mathrm{OH}, \mathrm{F})_{2}$ are always below 0.10 . The interlayer cations do not show marked deficiency (the sum is usually $1.76-1.86$ ). The excess of $(\mathrm{OH}+\mathrm{F})$ may be attributed partly to analytical errors and partly to substitution of $\mathrm{H}_{3} \mathrm{O}^{+}$ ions.

The pink muscovite surrounding the pseudomorphs was also generated during the alteration processes of topaz. The mica is poorer in $\mathrm{Fe}$ and richer in Mn than is the massive muscovite. The $\mathrm{Mn} / \mathrm{Fe}$ ratio is high (between 2 and 16) as it is in the pink or lilac muscovites described in the literature (Heinrich and Levinson 1953). The content of trace elements in the muscovite from the pseudomorphs after topaz is relatively low (Table 4). The pink muscovites are slightly enriched in $\mathrm{Rb}, \mathrm{Li}$ and $\mathrm{Cs}$ (see Table 4), probably because of being the last micas of the pseudomorphs to crystallize. Of the trace elements, Rb, Cs and Ga have become generally enriched in the muscovites, and $\mathrm{Li}, \mathrm{Be}$ and $\mathrm{Sr}$ in margarite.

The replacement of tourmaline and garnet by Fe-, Mn-, Mg- and Ti-bearing muscovite can also be accounted for by the alteration processes of topaz caused by potassium-bearing fluids. The muscovites differ in composition from those occurring in the pseudomorphs after topaz. The high concentrations of these above mentioned elements are due to the break-down products of the minerals. During the alteration of tourmaline, boron is assumed to form a sodiumtetraborate fluid that, together with the remaining alteration products, promotes precipitation of the last tourmaline generations in the replacement bodies and fracture fillings (cf. London 1986).

The sum of $\mathrm{Fe}, \mathrm{Mg}$ and $\mathrm{Mn} / \mathrm{O}_{20}(\mathrm{OH}, \mathrm{F})_{4}$ ranges between 0.23 and 0.53 in the muscovite from the pseudomorphs after tourmaline. Owing to Tschermak's substitution, the micas are enriched in $\mathrm{Si}^{(\mathrm{IV})}$, the range being $6.21-6.49 / \mathrm{O}_{20}$ $(\mathrm{OH}, \mathrm{F})_{4}$. The mica is poor in $\mathrm{Na}(\mathrm{Na} /(\mathrm{Na}+\mathrm{K})$ 
$=0.04-0.06$ ), and the sum of the interlayer cations is low, between 1.47 and 1.82 . The chemistry of the muscovite in the pseudomorphs after garnet in the Juurakko pegmatite seems to be similar. Correspondingly, hydrous phengitic muscovites have often been described from pseudomorphs after tourmaline and other ironbearing silicates in many pegmatites, although the chemistry of the micas depends largely on the composition of tourmaline and on the fluids (Mäkinen 1913, Quensel 1956, Haapala 1966, Foord 1976, Maleev et al. 1977).

\section{Chemistry of margarite in the pseudomorphs}

The composition of natural margarites varies within certain limits (Frey et al. 1982). The interlayer $\mathrm{Ca}$ may be partly replaced by $\mathrm{Na}$ and to compensate for the charge difference, Si replaces tetrahedral $\mathrm{Al}$, approaching the dioctahedral mica paragonite, $\mathrm{Na}_{2} \mathrm{Al}_{4} \mathrm{Si}_{6} \mathrm{Al}_{2} \mathrm{O}_{20}(\mathrm{OH}, \mathrm{F})_{4}$, in composition (Guidotti 1984). Lithium which replaces octahedral cations is usually a trace element in margarite, although some exceptional $\mathrm{Na}$ - and Li-bearing margarites have been reported in the literature. The composition gap between margarite and the trioctahedral Na-Li mica ephesite, $\mathrm{Na}_{2} \mathrm{Li}_{2} \mathrm{Al}_{4} \mathrm{Si}_{4} \mathrm{Al}_{4} \mathrm{O}_{20}(\mathrm{OH}, \mathrm{F})_{4}$, is, however, very large in natural micas (Grew et al. 1986). According to Schaller et al. (1967) and Guggenheim (1984), charge compensation in the Li substitution involves a coupled substitution $\mathrm{Na}^{+}, \mathrm{Li}^{+}=$ $\mathrm{Ca}^{2+}$, vacancy.

Margarites generally have a paragonite component of $10-30 \%$, rarely even up to $40 \%$, as a solid solution (Frey et al. 1982, Guidotti 1984 p. 362). Li- and Na-bearing margarites close in composition to the Juurakko margarite seem to be rare in nature, only a few analyses containing prominent Li having been documented. Margarite from Chester, Massachusetts, studied by Langer et al. (1981), and margarite from Greiner, Zillertal, Tirol, studied by Joswig et al. (1983), contain $0.43 \mathrm{wt} \% \mathrm{Li}_{2} \mathrm{O}$ and notable sodium. The occurrence of these micas has not, however, been described in detail. Grew et al. (1986) reported margarite with 0.17 wt $\% \mathrm{Li}_{2} \mathrm{O}$ from the peraluminous schists in Mount Bernstein, northern Victoria Land, Antarctica.

The Juurakko margarite is an intermediate form between margarite, paragonite and ephesite (Tables 1 and 2, see also the triangular diagram in Fig. 8). Calculated from the chemical analysis of the powdered sample, the endmember composition of the fibrous margarite is: margarite $57.9 \%$, paragonite $30.0 \%$, ephesite $9.6 \%$ and muscovite $2.5 \%$.

The $\mathrm{Si}^{(\mathrm{IV})} / \mathrm{Al}^{(\mathrm{IV})}$ ratio of the margarites studied in detail ranges between 1.08 and 1.36 , although as Figure 9 shows, the margarites have an excess of $\mathrm{Al}^{(\mathrm{IV})}$ and a deficiency of $\mathrm{Si}$ relative to the ideal solid solution of paragonite and margarite. The excess of $\mathrm{Al}$ is due to the solid solution of ephesite in margarite. Figure 9 shows that the analytical points are scattered over the margariteparagonite substitution line, obviously owing to the $\mathrm{Na}, \mathrm{Li}=\mathrm{Ca}$, vacancy replacement (cf. Frey et al. 1982). Unfortunately, the content of $\mathrm{Li}$ could not be determined with the microprobe.

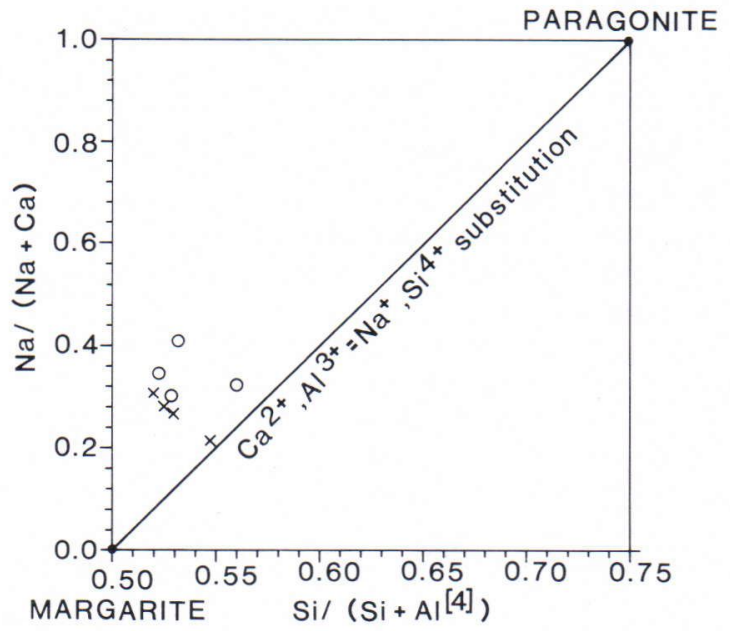

Fig. 9. The analytical data on the Juurakko margarite plotted in the $\mathrm{Na} /(\mathrm{Na}+\mathrm{Ca})$ versus $\mathrm{Si} /\left(\mathrm{Si}+\mathrm{Al}^{(\mathrm{IV})}\right)$ diagram. The figure shows that the Juurakko margarites have an excess of $\mathrm{Al}^{(\mathrm{IV})}$ and a deficiency of Si relative to the ideal solid solution of margarite and paragonite as a result of marked substitution of the ephesite component. 
Fluorine has seldom been analysed from margarite, and the concentrations, when reported, are very low (see e.g. Grew et al. 1986). The Juurakko margarite is slightly enriched in fluorine $(\mathrm{F} /(\mathrm{F}+\mathrm{OH})=0.16)$. This can be expected because the mineral crystallized as a result of the alteration processes of topaz.

Neither bityite nor beryllium margarite has been encountered in the Juurakko pegmatite. The concentration of $\mathrm{Be}$ in the fibrous margarite is low, $255 \mathrm{ppm}$, even though Be-bearing fluids were probably formed at the same time owing to the break-down processes of beryl. The bityites and beryllium margarites described in the literature always contain several per cent of berylli$\mathrm{um}$, and the micas are much richer in $\mathrm{Li}$ and poorer in Na (Lahti and Saikkonen 1985). The

\section{References}

Arnaudov, V.; Petrusenko, S. \& Pavlova, M., 1982. Berilijsdrzhashch margarit i fuksit ot desilitsirani pegmatiti v Rila. Bl'garska Akademija na Naukite. Geokhimiya, Mineralogiya i Petrologiya 15, 33-40.

Baltatzis, E. \& Katagas, C., 1981. Margarite pseudomorphs after kyanite in Glen Esk, Scotland. Am. Mineral. 66, 213-216.

Barton, M. D., 1982. The thermodynamic properties of topaz solid solutions and some petrologic applications. Am. Mineral. 67, 956-974.

Burt, D. M., 1976. Generation of high HF fugacities in miarolitic pegmatites and granites; the possible role of topaz. Annual Meeting, Geol. Soc. Am., Abstracts with program 8 , no. 6 .

-, 1981. Acidity-salinity diagrams - Application to greisen and porphyry deposits. Econ. Geol. 76, 832-843.

- \& London, D., 1982. Subsolidus equilibria. Mineral Association of Canada Short Course Handbook 8, 329-346.

Černý, P., 1968. Beryllumwandlungen in Pegmatiten Verlauf und Produkte. N. Jb. Miner. Abh. 108, 166-180.

—, \& Burt, D. M., 1984. Paragenesis, crystallochemical characteristics and geochemical evolution of micas in granite pegmatites. In Bailey, S. W. (ed.) Reviews in Mineralogy 13, Min. Soc. America, pp. 257-297.

Foord, E. E., 1976. Mineralogy and petrogenesis of layered pegmatite-aplite dikes in the Mesa Grande district, San Diego County, California. Ph.D. thesis, Stanford University, 326 p.
Li content of the hydrothermal fluids that caused the alteration of beryl, topaz and other silicates was probably so low that no bityite or beryllium margarite could crystallize.

Acknowledgements. I am indebted to my sons Miikka and Jari, the two keen mineral collectors, who assisted me in the field work at the Juurakko quarry and found some of the specimens described in the study. My sincere thanks are also due to Mr. Seppo Sivonen, University of Oulu, and to Mr. Bo Johanson, Geological Survey of Finland for the microprobe analyses. Mr. Risto Saikkonen, Mr. Cristian Backman, Mr. V. Hoffren and Mrs. Eeva Kallio carried out many of the other chemical determinations at the Geological Survey of Finland. Mr. Jukka Keskinen took the photographs and helped in many ways during the laboratory studies. Dr. Kai Hytönen and Mr. Kristian Lindquist and Pekka Kallio kindly read the manuscript and offered constructive criticism. Mrs. Gillian Häkli corrected the English of the manuscript. I am very grateful to all these persons for their help.

Frey, M.; Bucher, K.; Frank, E. \& Schwander, H., 1982. Margarite in the Alps. Schweiz. mineral. petrog. Mitt. 62, $21-45$.

Grew, E. S.; Hinthorne, James R. \& Marquez, Nicholas, 1986. $\mathrm{Li}, \mathrm{Be}$ and $\mathrm{Sr}$ in margarite and paragonite from Antarctica. American Mineral. 71, 1129-1134.

Grigor'ev, D. P., 1965. Ontogeny of minerals. Transl. ed. by Y. Brenner. Israel Program for Scientific Translations Ltd., $250 \mathrm{p}$.

Grigor'ev, Iv. F. \& Dolomanova, E. I., 1954. Topaz iz mestorozhdenij kassiteritovo-kvartsevoj formatsii Zabajkalya i ego metasomatichseskie izmeneniya. Akad. Nauk SSSR. Trudy Min. Muz. 6, 84-116.

Guggenheim, S., 1984. The brittle micas. In Bailey, S. W. (ed.) Reviews in mineralogy, 13. Min. Soc. Am., pp. 61-104.

Guidotti, C. V., 1984. Micas in metamorphic rocks. In Bailey, S. W. (ed.) Reviews in mineralogy, 13. Min. Soc. Am., pp. $357-467$.

— \& Cheney, J. T., 1976. Margarite pseudomorphs after chiastolite in the Rangeley area, Maine. American Mineral. $61,431-432$.

Haapala, I., 1966. On the granitic pegmatites in the Peräseinäjoki-Alavus area, South Pohjanmaa, Finland. Bull. Comm. Geol. Finlande 224, 98 p.

Hawthorne, F. C. \& Černý, P., 1982. The mica group. In Černý, P. (ed.) Short Course in Granitic pegmatites in Science and Industry. Mineralogical Association of Canada, pp. 63-98.

Heinrich, E. Wm. \& Levinson, A. A., 1953. Studies in the 
mica group; Mineralogy of the rose muscovites. Am. Mineral. 38, 25-49.

Jahns, R. H., 1953. The genesis of pegmatites. 2. Quantitative analysis of lithium-bearing pegmatite, Mora County, New Mexico. Am. Mineral. 38, 1078-1112.

— \& Ewing R. C., 1976. The Harding mine, Taos County, New Mexico. Mineral. Record 8, 115-126.

Joswig, W.; Takeuchi, Y. \& Fuess, H., 1983. Neutrondiffraction study on the orientation of hydroxyl groups in margarite. Zeitschr. Krist. 165, 295-303.

Kelly, W. C. \& Rye, R. O., 1979. Geologic, fluid inclusion, and stable isotope studies of the tin-tungsten deposits of Panasqueira, Portugal. Econ. Geol. 74, 1721-1822.

Kornetova, V. A., 1954. Psevdomorfozy slyudy po topazu v pegmatitakh vostochnogo Zabajkal'ya. Akad. Nauk. SSSR, Trudy Min. Muz. 6, 142-144.

Kutukova, E. I., 1959. Berillijsoderzhashchij margarit so strednego Urala. Akad. Nauk SSSR, Inst. Mineral Geohim. Kristallokhim. Redkikh Elem. 3, 79-84.

Lahti, S. I., 1981. On the granitic pegmatites of the Eräjärvi area in southern Finland. Geol. Surv. Finland, Bull. 314, $82 \mathrm{p}$.

-, 1986. The granite pegmatites of the Eräjärvi district. In Laitala, M. (ed.) Guide 4, Geological Survey of Finland, 17e Nordiska Geologmötet 1986, Excursion Guide, excursion Al, Precambrian Geology, southern Finland, pp. $42-46$.

— \& Saikkonen, R., 1985. Bityite $2 \mathrm{M}_{1}$ from Eräjärvi compared with related Li-Be brittle micas. Bull. Geol. Soc. Finland 57, 207-215.

Laitakari, I., 1986. Pre-Quaternary rocks, Sheet 2142 Orivesi, Geological map of Finland 1: 100000.

Langer, K.; Chatterjee, N. D. and Abraham, K., 1981. Infrared studies of some synthetic and natural $2 \mathrm{M}_{1}$ dioctahedral micas. N. Jb. Mineral. Abh. 142, 91-110.

London, D., 1986. Magmatic-hydrothermal transition in the Tanco rare-element pegmatite: Evidence from fluid inclusions and phase-equilibrium experiments. Am. Mineral. $71,376-395$.
Mäkinen, E., 1913. Die Granitpegmatite von Tammela und ihre Minerale. Bull. Comm. Geol. Finlande 35, 101 p.

Maleev, M. N.; Dimitrova, G. H. \& Landzheva, E. N., 1977. Khidromuskovitovi psevdomorfozi po turmalin ot Vitosha. Godishnik na Sofijskija Universitet, GeologoGeografiski Fakultet, kniga 1, 69, 107-114.

Marchenko, E. Ya. \& Polynovs'kij, R. M., 1970. Pro zamishchennya topazu voloknistim muskovitom. Dokl. Akad. Nauk. Ukrainskoj RSR, B 11, 979-982.

Matisto, A., 1964. Pre -Quaternary rocks, Sheet 2141 Kangasala. Geological map of Finland, $1: 100000$.

—, 1976. Kangasalan kartta-alueen kallioperä. Summary: Precambrian rocks of the Kangasala map-sheet area. Geological map of Finland 1: 100 000, Explanation to the map of 2141 Kangasala. 27 p.

Quensel, P., 1955. The paragenesis of the Varuträsk pegmatite including a review of its mineral assemblage. Ark. Mineral. Geol. 2, 9-125.

Roering, C. \& Heckroodt, R. O., 1964. The alteration of beryl in the Dernburg pegmatite, Karibib, South West Africa. Annals of the Geol. Surv. South Africa 3, 133-137.

Rosenberg, P. E., 1972. Paragenesis of the topaz-bearing portion of the Brown Derby No. 1 pegmatite, Gunnison County, Colorado. Am. Mineral. 57, 571-583.

Rutstein, M. S., 1979. Fibrous intergrowths of cross muscovite and cross chlorite from shear zones of Pennsylvanian carbonaceous rocks in Rhode Island. Am. Mineral. 64, 151-155.

Schaller, W. T.; Maxwell, K. C. \& Fleischer, M., 1967. Ephesite $\mathrm{Na}\left(\mathrm{Li}, \mathrm{Al}_{2}\right)\left(\mathrm{Al}_{2} \mathrm{Si}_{2}\right) \mathrm{O}_{10}(\mathrm{OH})_{2}$, a trioctahedral member of the margarite group, and related brittle micas. Am. Mineral. 52, 1689-1696.

Storre, B. \& Nitsch, K.-H., 1974. Zur Stabilität von Margarit im System $\mathrm{CaO}-\mathrm{Al}_{2} \mathrm{O}_{3}-\mathrm{SiO}_{2}-\mathrm{H}_{2} \mathrm{O}$. Contr. Mineral. Petrol. 43, 1-24.

Received November 3, 1987

Revised and accepted January 15, 1988 